ISSN 0258-7122

Bangladesh J. Agril. Res. 40(4): 669-682, December 2015

\title{
FARM LEVEL IMPACT STUDY OF POWER TILLER OPERATED SEEDER ON SERVICE PROVIDERS' LIVELIHOOD IN SOME SELECTED SITES OF BANGLADESH
}

\author{
M. A. Monayem MiaH ${ }^{1}$ AND M. ENAMUl HaQUE ${ }^{2}$
}

\begin{abstract}
The custom hiring of power tiller operated seeder (PTOS) is highly profitable at farm level and service providers could improve their livelihood through this machine. The data and information on these aspects are scarce in Bangladesh. Therefore, an attempt was made to conduct this study to assess the uses pattern and the impacts of PTOS operations on service providers' livelihood. A total of 53 service providers were randomly selected and interviewed for this study from Dinajpur and Rajbari districts. The study revealed that most respondents provided PTOS services almost throughout the year. The custom hiring of PTOS created many positive impacts on the livelihoods of the service providers. PTOS made a remarkable improvement in the livelihoods of its service providers in the study areas. The respondent service providers experienced a considerable increase in their land holdings (8.6\%), annual income (63.4\%), livestock resources (44\%), farm equipment (20\%), household assets position, and dwelling houses $(42 \%)$. The increased income of beneficiaries are mostly spent on farm machinery, nutritious food, cloths, health care, education, and making of houses that indicate higher standard of riding to some extent, compared to pre PTOS service period. The service providers faced some problems like higher fuel cost, lack of riving facility, non-availability and higher price of spare parts, roller jam, and lack of trained driver. Financial support and technical assistance regarding PTOS should be made available by the government for service providers and local manufacturers for the higher adoption of PTOS in Bangladesh.
\end{abstract}

Keywords: PTOS, custom hire, service provider, livelihood.

\section{Introduction}

Most tillage operations in Bangladesh are now done by power tiller (PT) for lower cost and require less time for cultivation (Islam, 2000; Miah, 2000; Barton, 2000; Miah et al., 2002; Haque et al., 2008). This tillage implement is introduced basically for land preparation, but now it is used for different purposes depending on environment, ability of farmers for buying attachments, and availability of credit facilities. The percentage of area cultivated under PT is $67 \%$ and the average growth rate of power tillers in Bangladesh was 21\% during 1993-2003

${ }^{1}$ Senior Scientific Officer, Agricultural Economics Division, Bangladesh Agricultural Research Institute (BARI), Joydebpur, Gazipur-1701, Bangladesh, ${ }^{2}$ Adjunct Associate Professor, Murdock University, Australia, and Team Leader, Conservation Agriculture Project, IDE Bangladesh, Gulshan, Dhaka-1212, Bangladesh. 
(Quayum and Ali, 2012). There are about 7,00,000 PTs in Bangladesh (Hossain, 2014). The traditional tillage method reduces soil organic carbon at double rate and decreases soil fertility (Grace, 2003), losses irrigation water and soils (Sayre and Hobbs, 2003), and damages ecological environment (Grace, 2003). Therefore, the concept of conservation tillage has been arisen all over the world which is relatively new in Bangladesh.

PTOS is a two wheel tractor operated seed drill and widely used for various crop establishments through conservation tillage, sowing of seeds and laddering operations are done simultaneously in a single pass in many areas of Bangladesh. Three operations could be done in one operation, i.e., prepare lands with fine tilth, sowing seeds at the $2-3 \mathrm{~cm}$ depth and planking simultaneously. It performs well at 15 to $36 \%$ of soil moisture level. If optimum soil moisture exists, it could reduce turn-around-time up to zero days in between two crops establishment. It's width of operation is $120 \mathrm{~cm}$ having six rows sowing capacity at a time.

The service providers remove seeding unit from PTOS and convert only for High Speed Rotary Tiller (HSRT). Most of the grain seeds like wheat, paddy, maize, jute, pulses, oilseeds etc are sown in line using PTOS. The owners of PTOS are using this device for their own land cultivation and earning cash income through custom hiring to other farmers. The use of PTOS is getting popularity throughout the country since its spare parts, repair and maintenance mechanics and workshops are available at the village level. Nevertheless, the custom hiring of PTOS is highly profitable at farm level (Miah et al. 2010) and many service providers could improve their livelihood through this machine. The socioeconomic impacts of this popular conservation tillage implement have not been done in the country. Therefore, an attempt was made to conduct this study with the following objectives.

\section{Objectives}

a) To describe the socio-economic profile of the PTOS service providers;

b) To determine the impacts of PTOS on the livelihoods of service providers; and

c) To find out the uses pattern and problems of PTOS at service providers' level.

\section{Methodology}

Sampling and data collection: The present study followed purposive sampling technique in order to select study areas and sample service providers. At first stage of sampling, four Upazillas namely Bochagonj, Fulbari and Dinajpur Sadar under Dinajpur district and Baliakandi under Rajbari district were purposively selected for the study. The reason of this selection was that PTOS is being widely 
used in the aforesaid study areas. In Rajbari, PTOS is being used for sowing wheat, jute, and sesame seed directly. In Dinajpur, it is widely used for planting the seeds of wheat, maize, chickpea, lentil, mungbean, jute and sesame. Nevertheless, PTOS is also being used for land preparation for transplanting onion and garlic seedlings, paddling rice field in both the areas.

A total of 53 service providers ${ }^{1}$ taking 47 persons from Rajbari and six persons from Dinajpur district were randomly selected for the study. Data and information were gathered from selected service providers of PTOS through conducting household survey using pre-tested interview schedules during July, 2008 .

Analytical technique: The collected data were scrutinized, edited, tabulated, and analyzed for fulfilling the objectives of the study. The impacts of PTOS on the livelihoods of service providers were assessed through analyzing 'Before' and 'After' socio-economic standings of the service providers. Data regarding land holdings, livestock resources, yearly household income, farm equipment, household assets, liability status, and food intake were analyzed and compared for measuring the impacts of PTOS service on its provider's livelihoods. The values of different household assets were collected based on present value. For example, a house was built five years back with the amount of Tk.50,000 but due to price hiking, the present value of this house is Tk.70,000 which is used for reporting. Besides, if that farmer invested extra money for renovation and/or extension of the house that amount is also added with the present value in this report. T-test was also employed to show the level of significant difference between two periods. Tabular method of analysis with descriptive statistics was adopted to present the findings of the study.

\section{Results and Discussion}

\subsection{Socioeconomic Profile of PTOS Service Providers}

Socio-economic characteristics of the farmers are important in influencing farm decision making and production planning. There are numerous interrelated and constituent attributes that characterize a person and these profoundly influence development behavior. Some related socioeconomic characteristics of the PTOS Service Providers are shown in Table 1.

Age is an important factor that may be influenced entrepreneurs' decision to operate PTOS as a commercial business. The average age of the respondents was 40 years with minimum age of 23 years and the maximum of 90 years. They were grouped into five categories based on their level of education. More than $47 \%$ of them completed secondary levels of education, followed by $34 \%$ of

${ }^{1}$ Prepared land on contractual basis. 
primary level. Only $3.8 \%$ were found to complete their higher level of education. Only $2 \%$ service providers were not received any formal education. The average length of experience of service providers in PTOS operations was four years ranging from two to six years. Most of them were experienced by three years. Three types of financing sources were reported in the study areas. More than half of the respondents bought PTOS by own cash, cash from commercial banks or PTOS sellers and from CIMMYT. A good number of service providers bought by own cash. Many service providers owned a number of farms implement namely power tiller, power thresher, shallow tube well (STW), sprayer and hand weeder that were mostly used for renting out to others for earning cash income. Nearly $86 \%$ of sample PTOS owners owned STW, 39.6\% owned power thresher and $18.9 \%$ owned sprayer. Furthermore, $26.4 \%$ of them bought an additional power tiller for their own use as well as service providing business (Table 1).

Table 1: Socioeconomic profile of PTOS service provider in the study areas.

\begin{tabular}{l|c|c}
\hline \multicolumn{1}{c}{ Items } & Frequency & Mean \\
\hline 1. Farmers' age (year) & 53 & 40.0 \\
2. Level of education (\%) & 2 & \\
a. Illiterate & 18 & 3.8 \\
b. Completed primary level & 25 & 34.0 \\
c. Completed secondary level & 6 & 47.2 \\
d. Completed higher secondary level & 2 & 11.3 \\
e. Degree and above & & 3.8 \\
3. Experience with PTOS service (\%) & 2 & \\
a. 6 years (2002/03 to 2007/08) & 6 & 3.8 \\
b. 5 years (2003/04 to 2007/08) & 9 & 11.3 \\
c. years (2004/05 to 2007/08) & 23 & 17.0 \\
d. 3 years (2005/06 to 2007/08) & 13 & 43.4 \\
e. 2 years (2006/07 to 2007/08) & & 24.5 \\
4. Source of financing for PTOS (\%) & 24 & \\
a. Self & 2 & 45.3 \\
b. Credit & 27 & 3.8 \\
c. Both self \& credit & & 50.9 \\
5. Type of farm machineries owned (\%) & 14 & \\
a. Power tiller & 21 & 26.4 \\
b. Power thresher & 45 & 39.6 \\
c. Shallow tube well & 10 & 86.8 \\
d. Sprayer & 7 & 18.9 \\
e. Hand weeder & & 13.2 \\
\hline
\end{tabular}




\subsection{Uses Pattern and Trend of PTOS Operations}

The sample service providers provided PTOS services almost throughout the year. They rented out PTOS services for land preparation for sowing and transplanting seeds/seedlings of different crops. Onion transplanting requires fine tilth of soil. So, the highest land preparation was for onion followed by rice and jute in the study areas. The period ranged from mid-October to mid-January was reported to be the peak season of PTOS service since most of the Rabi crops are grown within these periods. Contrarily, the periods ranged from mid-August to mid-October and mid-May to mid-June were treated as lean period for PTOS service (Fig-1).

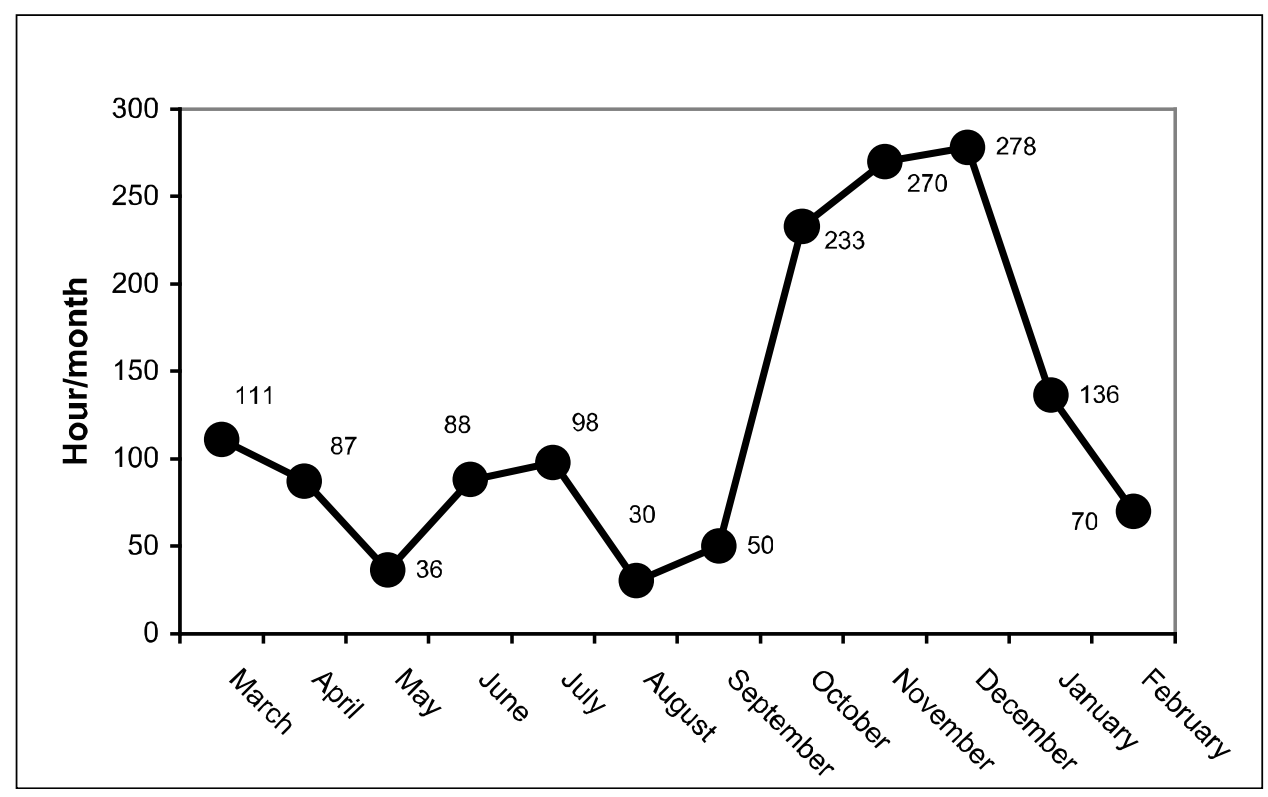

Fig. 1. Seasonality of PTOS in the study areas.

\subsection{Socioeconomic Impacts of PTOS on Service Providers' Livelihood}

A livelihood is a means of making a living. It encompasses people's capabilities, assets, income, and activities required to secure the necessities of life. In another words, livelihood is defined as a set of activities, involving securing water, food, fodder, medicine, shelter, clothing, and the capacity to acquire above necessities working either individually or as a group by using endowments for meeting the requirements of a household (http://en.wikipedia.org/wiki/ Livelihood). Livelihood development is a broad issue usually which depends on the wider economic development of the society. It was reported that PTOS had positive and direct effects on its owners in generating employment and income; creating household assets, and increasing the standard of living to a great extent in the 
study areas. It was somewhat difficult to assess the socioeconomic impacts of PTOS on the livelihoods of service providers because many factors might be contributed to uplift their standard of living. However, the socioeconomic impacts of PTOS on the livelihoods of service providers are discussed in the following sections.

Impact on land holdings: Table 2 shows that the land holding size of the service providers increased to some extent along with different land categories after having PTOS. Irrespective of providers' categories, the average holding size was increased by $8.6 \%$. Significant change was occurred in the mortgaged-in land that might be due to the direct effect of PTOS service. The amount of rented-in land was decreased by $2.9 \%$ and rented-out land was increased by $5.5 \%$ implying the economic upliftment of the service providers in the study areas.

Table 2. Change in farm size before and after ownership of PTOS in the study area.

\begin{tabular}{l|c|c|c|c|c}
\hline \multicolumn{1}{c}{ Land category } & $\mathrm{N}$ & $\begin{array}{c}\text { After having } \\
\text { PTOS }\end{array}$ & $\begin{array}{c}\text { Before } \\
\text { having PTOS }\end{array}$ & $\begin{array}{c}\text { Mean } \\
\text { difference }\end{array}$ & $\begin{array}{c}\text { P(T<=t) } \\
\text { value }\end{array}$ \\
\hline 1. Own land & 51 & 2.392 & 2.347 & 0.045 & 0.9198 \\
2. Rented in & 14 & 0.381 & 0.392 & -0.011 & 0.9571 \\
3. Rented out & 19 & 0.492 & 0.466 & 0.027 & 0.8600 \\
4. Mortgaged in & 33 & 0.337 & 0.076 & $0.260^{* * *}$ & 0.0000 \\
5. Mortgaged out & 14 & 0.310 & 0.183 & 0.127 & 0.2481 \\
6. Homestead & 53 & 0.136 & 0.114 & 0.022 & 0.2820 \\
7. Orchard & 39 & 0.112 & 0.085 & 0.027 & 0.3353 \\
8. Pond & 44 & 0.129 & 0.106 & 0.023 & 0.3742 \\
*Farm size & 53 & 2.685 & 2.472 & $0.212(8.6)$ & 0.6104 \\
\hline
\end{tabular}

Note: $* * *$ indicates significant at $1 \%$ level. Figure in the parenthesis indicates percent increased over pre-ownership period.

*Farm size $=($ Own land + Rented in + Mortgaged in + Homestead + Orchard + Pond $)-($ Rented out+ Mortgaged out)

Impact on livestock resources: Due to the increased income of the service providers that earned from renting out PTOS service, the most livestock and poultry resources were increased during post-ownership period. Remarkable decrease was found in the quantity of bullocks, but significant increase was registered in the value of calves (which will be ultimately milking cows), goats and adult chickens (Table 3 ). 
Table 3. Change in livestock resources before and after ownership of PTOS

\begin{tabular}{l|c|cc|c|c|cc}
\hline \multirow{2}{*}{$\begin{array}{c}\text { Livestock and } \\
\text { poultry }\end{array}$} & $\mathrm{N}$ & \multicolumn{2}{c}{ After having PTOS } & \multicolumn{2}{c}{ Before having PTOS } & \multicolumn{2}{c}{ Mean difference } \\
\cline { 3 - 8 } & & Quantity & Value (Tk) & Quantity & Value (Tk) & Quantity & Value (Tk) \\
\hline 1. Bull/Ox & 24 & 0.93 & 11691 & 1.52 & 13122 & $-0.59^{* * * *}$ & -1431 \\
2. Cow & 48 & 1.83 & 26669 & 1.56 & 21792 & 0.27 & 4877 \\
3. Calves & 40 & 1.33 & 9500 & 1.00 & 4095 & 0.33 & $5405^{* * *}$ \\
4. Goat & 33 & 3.48 & 5979 & 1.91 & 2218 & 1.57 & $3761^{* * *}$ \\
5. Duck (Adult) & 36 & 6.81 & 818 & 3.28 & 432 & 3.53 & 386 \\
6.Chicken (Adult) & 39 & 8.46 & 1204 & 6.64 & 793 & 1.82 & $411^{*}$ \\
All types & & 22.84 & 55861 & 15.91 & 42452 & $6.93(44)$ & $13409(32)$ \\
\hline
\end{tabular}

Note: $* * *$ and $*$ indicate significant at $1 \%$ and $10 \%$ level, respectively.

Figures in the parentheses indicate percent increased over pre-ownership period.

Impact on household income: The principal components of household income of the service providers were crop farming, service, farm machinery, business, and livestock and poultry farming. Table 4 shows the remarkable positive impact of PTOS on the annual income of the service providers in the study areas. The annual household income was significantly increased by $63.4 \%$ during postownership period. The percent increase in income was found to be highest in case of farm machineries followed by livestock rearing and crop production. The service providers earned $19 \%$ of total income from PTOS. They stated that it could be possible for them to buy other farm machineries like power tiller (PT), STW, and thresher by the income received from PTOS.

Table 4. Change in yearly household income before and after ownership of PTOS.

\begin{tabular}{l|r|c|c|c|c}
\hline \multicolumn{1}{c}{ Income source } & $\mathrm{N}$ & $\begin{array}{c}\text { After having } \\
\text { PTOS }\end{array}$ & $\begin{array}{c}\text { Before having } \\
\text { PTOS }\end{array}$ & $\begin{array}{c}\text { Mean } \\
\text { difference }\end{array}$ & $\begin{array}{c}\mathrm{P}(\mathrm{T}<=\mathrm{t}) \\
\text { value }\end{array}$ \\
\hline 1. Crop production & 53 & $236460(34)$ & $179933(53)$ & $56527 *$ & 0.073 \\
2. Service & 15 & $140703(20)$ & $80933(24)$ & 59770 & 0.289 \\
3. Business & 13 & $51846(8)$ & $41615(12)$ & 10231 & 0.443 \\
4. Livestock & 40 & $18672(3)$ & $10097(3)$ & $8575 * * *$ & 0.008 \\
5. Fruit sale & 6 & $7767(1)$ & $7300(2)$ & 467 & 0.959 \\
6. Farm machinery & 143 & $231851(34)$ & $20874(6)$ & $210977 * * *$ & 0.000 \\
PTOS & 53 & $130510(19)$ & 0 & 130510 & - \\
PT & 36 & $44833(7)$ & $8194(2)$ & $36639 * * *$ & 0.000 \\
STW & 35 & $11929(2)$ & $2943(1)$ & $8986 * * *$ & 0.000 \\
Thresher & 19 & $44579(6)$ & $9737(3)$ & $34842 *$ & 0.062 \\
\hline Total (Tk/year) & 53 & $687299(100)$ & $340752(100)$ & $216037 * * *$ & 0.002 \\
\hline
\end{tabular}

Note: $* * *$ and $*$ indicate significant at $1 \%$ and $10 \%$ level, respectively.

Figures within parentheses are the percentages of total income. 
Impact on farm equipment: Increasing the household assets is closely related to the financial condition of the service providers of PTOS. Renting out of PTOS service in the study areas has boosted up their asset position to a great extent. Table 5 revealed that the total quantity and value of farm equipment was increased by $20 \%$ and $239 \%$ respectively during post-ownership period of PTOS. Most service providers mentioned that they purchased modern farm equipment like PT, STW, thresher, and sprayer by the income that earned from renting out of PTOS service. That's why the highest and significant increases were apparent both in the number and value of STW, hand tube well (HTW), thresher, and sprayer. Besides, the number of wooden plough decreased with the increase in the use of PT and PTOS.

Table 5. Change in farm equipment before and after ownership of PTOS.

\begin{tabular}{l|c|c|c|ccc|c|c}
\hline \multirow{2}{*}{ Farm equipment } & \multirow{2}{*}{$\mathrm{N}$} & \multicolumn{2}{|c|}{$\begin{array}{c}\text { After having } \\
\text { PTOS }\end{array}$} & \multicolumn{2}{c|}{$\begin{array}{c}\text { Before having } \\
\text { PTOS }\end{array}$} & \multicolumn{2}{c}{ Mean difference } \\
\cline { 3 - 8 } & & Quantity & Value & Quantity & Value & Quantity & Value \\
\hline 1. PTOS & 48 & 1.02 & 81,590 & 0 & 0 & 1.02 & $81,590^{* * *}$ \\
2. Power tiller & 25 & 1.00 & 54,760 & 0.64 & 35,620 & 0.36 & $19,140^{*}$ \\
3. STW & 49 & 1.08 & 15,106 & 0.65 & 8,551 & $0.43^{* * *}$ & $6,555^{*}$ \\
4. HTW & 53 & 1.28 & 7,404 & 0.89 & 4,726 & $0.39^{* * *}$ & $2,678^{* * *}$ \\
5. Sprayer & 23 & 1.13 & 2,355 & 0.65 & 527 & $0.48^{* * *}$ & 1,828 \\
6. Thresher & 22 & 1.14 & 32,414 & 0.50 & 5,732 & $0.64^{* *}$ & $26,682^{* * *}$ \\
7. Wooden plough & 27 & 0.19 & 52 & 1.44 & 743 & $-1.25^{* * *}$ & $-691^{* * *}$ \\
8. Ladder & 50 & 1.36 & 372 & 1.40 & 403 & -0.04 & -31 \\
\hline \multicolumn{1}{c}{ Total } & & 8.2 & 194,053 & 6.17 & 56,302 & 2.03 & $1,37,751^{* * *}$ \\
& & & & & $(33)$ & $(245)$ \\
\hline
\end{tabular}

Note: $* * *, * *$ and $*$ indicate significant at $1 \%, 5 \%$ and $10 \%$ level, respectively.

Figures in the parentheses indicate percent increased over pre-ownership period.

Impact on household assets: Due to increased income, the housing assests of all service providers of PTOS has improved to a great extent. They have made remarkable improvements in their dwelling houses and kitchens during postownership period. Table 6 revealed that the number and value of semi-pacca building were significantly increased by $42 \%$ and $69 \%$ respectively during postownership period. On the contrary, the numbers of Katcha-pacca and Katcha houses decreased by $3.7 \%$ and $17.1 \%$ respectively. Remarkable improvements were also found in the number and value of both semi-pacca and Katcha-pacca kitchen. Most sample service providers had to construct more number of valuable store houses due to increase in both crop production and household assets. 
Table 6. Change in house types before and after ownership of PTOS.

\begin{tabular}{|c|c|c|c|c|c|c|c|}
\hline \multirow[b]{2}{*}{ House type } & \multirow[b]{2}{*}{$\mathrm{N}$} & \multicolumn{2}{|c|}{ After having PTOS } & \multicolumn{2}{|c|}{ Before having PTOS } & \multicolumn{2}{|c|}{ Mean difference } \\
\hline & & Quantity & $\begin{array}{l}\text { Value } \\
(\mathrm{Tk})\end{array}$ & Quantity & Value (Tk) & Quantity & $\begin{array}{l}\text { Value } \\
\text { (Tk) }\end{array}$ \\
\hline 1.Dwelling house & & 7.07 & 529128 & 5.86 & 218224 & 1.21 & 310904 \\
\hline Pacca $^{l}$ & 4 & 1.75 & 202500 & 1.00 & 10000 & 0.75 & 192500 \\
\hline Semi-pacca ${ }^{2}$ & 42 & 2.40 & 236310 & 1.69 & 139929 & $0.71 * *$ & $96381 * *$ \\
\hline Katcha-pacca ${ }^{3}$ & 19 & 1.32 & 49318 & 1.37 & 40895 & -0.05 & 8423 \\
\hline Katcha $a^{4}$ & 5 & 1.60 & 41000 & 1.80 & 27400 & -0.20 & 13600 \\
\hline 2. Kitchen & & 3.28 & 93029 & 2.81 & 69319 & 0.47 & 23710 \\
\hline Pacca & 2 & 1.00 & 50000 & 1.00 & 50000 & 0 & 0 \\
\hline Semi-pacca & 19 & 1.11 & 29000 & 0.84 & 13968 & $0.27 * *$ & $15032 * *$ \\
\hline Katcha-pacca & 35 & 1.17 & 14029 & 0.97 & 5351 & 0.20 & $8678 * *$ \\
\hline 3. Other houses & & 3.66 & 58656 & 3.14 & 43600 & 0.52 & 15056 \\
\hline Cow shed & 43 & 1.12 & 26988 & 1.10 & 18290 & 0.02 & 8698 \\
\hline Poultry shed & 25 & 1.44 & 1768 & 1.24 & 1510 & 0.20 & 258 \\
\hline Storehouse & 10 & 1.10 & 29900 & 0.80 & 23800 & $0.30^{* * *}$ & 6100 \\
\hline
\end{tabular}

Note: ${ }^{1}$ House with concrete roof and brick wall.

${ }^{2}$ House with corrugated iron (CI) sheet roof and brick wall.

${ }^{3}$ House with CI sheet roof and thrashed bamboo/jute stick/straw wall.

${ }^{4}$ House with straw roof and thrashed bamboo/jute stick/straw wall.

$* * *, * *$ and $*$ indicate significant at $1 \%, 5 \%$ and $10 \%$ level, respectively.

Providing PTOS service has incredible impact in increasing the household assets in the study areas. Table 7 shows the comparative scenarios of the household asset positions of PTOS service providers. The quantity and quality (in terms of value) of different types of furniture, modern amenities and other household assets of the service providers were significantly increased after having PTOS. However, no change was made in the quantity and quality of Chowki, radio and boat in the study areas.

Impact on liabilities: The service providers of PTOS were reported to be received loan from commercial bank, cooperative society, and local NGOs and borrowed money from moneylender, relatives, and many other sources for various purpose. Table 8 revealed that the average amount of loan received during PTOS ownership period was about 50.5\% higher than that of preownership period that might be due to purchase of PTOS and related accessories. This scenario also clearly indicates their higher access to the institutional credit facility in study areas. 
Table 7. Change in household assets before and after ownership of PTOS.

\begin{tabular}{|c|c|c|c|c|c|c|c|}
\hline \multirow{2}{*}{$\begin{array}{l}\text { Household } \\
\text { assets }\end{array}$} & \multirow{2}{*}{$\mathrm{N}$} & \multicolumn{2}{|c|}{ After having PTOS } & \multicolumn{2}{|c|}{ Before having PTOS } & \multicolumn{2}{|c|}{ Mean difference } \\
\hline & & Quantity & $\begin{array}{l}\text { Value } \\
(\mathrm{Tk})\end{array}$ & Quantity & $\begin{array}{l}\text { Value } \\
(\mathrm{Tk})\end{array}$ & Quantity & $\begin{array}{l}\text { Value } \\
(\mathrm{Tk})\end{array}$ \\
\hline 1. Furniture & & 27.35 & $\mathbf{5 7 , 5 9 2}$ & 14.12 & 23,944 & 13.23 & 33648 \\
\hline Cot & 38 & 3.16 & 24,066 & 1.37 & 9,408 & $1.79 * * *$ & $14658 * * *$ \\
\hline Chowki $^{1}$ & 50 & 3.18 & 3,942 & 2.88 & 3,912 & 0.30 & 30 \\
\hline Almirah & 36 & 1.64 & 9,500 & 0.72 & 3,819 & $0.92 * * *$ & $5681 * * *$ \\
\hline Dressing table & 25 & 1.56 & 5,544 & 0.24 & 1,000 & $1.32 * * *$ & $4544 * * *$ \\
\hline Tables & 53 & 2.79 & 3,104 & 1.34 & 1,340 & $1.45 * * *$ & $1764 * * *$ \\
\hline Chairs & 52 & 5.75 & 2,578 & 2.90 & 1,099 & $2.85 * * *$ & $1479 * * *$ \\
\hline Bench & 36 & 1.19 & 785 & 0.89 & 538 & $0.30 *$ & $247 * *$ \\
\hline Dress-stand & 48 & 2.75 & 2,543 & 1.27 & 1,115 & $1.48 * * *$ & $1428 * * *$ \\
\hline Basket (large) & 42 & 2.26 & 4,802 & 1.10 & 1,429 & $1.16 * * *$ & $3373 * * *$ \\
\hline Tool $^{2}$ & 41 & 3.07 & 728 & 1.41 & 284 & $1.66 * * *$ & $444 * * *$ \\
\hline 2.Modern amen & lities & 12.98 & 120,376 & 5.75 & 26,509 & 7.23 & 93867 \\
\hline Mobile phone & 47 & 1.81 & 7,569 & 0.15 & 543 & $1.66 * * *$ & $7026 * * *$ \\
\hline Motor cycle & 14 & 1.14 & 95,786 & 0.29 & 19,643 & $0.85 * * *$ & $76143 * * *$ \\
\hline Television & 35 & 1.31 & 11,589 & 0.49 & 3,397 & $0.82 * * *$ & $8192 * * *$ \\
\hline Cassette player & 24 & 0.92 & 2,119 & 0.50 & 1,313 & $0.42 * * *$ & $806^{*}$ \\
\hline Radio & 32 & 0.88 & 352 & 0.88 & 352 & 0 & 0 \\
\hline Wrist watch & 41 & 2.49 & 1,390 & 1.39 & 599 & $1.10 * *$ & $791 * * *$ \\
\hline Table/wall clock & 45 & 1.91 & 573 & 0.78 & 228 & $1.13 * * *$ & $345 * * *$ \\
\hline Torch light $^{3}$ & 48 & 2.52 & 998 & 1.27 & 434 & $1.25 * * *$ & $564 * * *$ \\
\hline 3. Other assets & & 3.68 & 18,892 & 2.74 & 14,927 & 0.94 & 3965 \\
\hline Bicycle & 47 & 1.79 & 6,004 & 1.23 & 3,574 & $0.56 * *$ & $2430 * * *$ \\
\hline Rickshaw/van & 26 & 0.92 & 3,312 & 0.54 & 1,777 & $0.38 * * *$ & $1535^{* * * *}$ \\
\hline Boat & 33 & 0.97 & 9,576 & 0.97 & 9,576 & 0 & 0 \\
\hline
\end{tabular}

${ }^{1}$ a four legged wooden bedstead; ${ }^{2}$ a wooden seat without a back for one person; ${ }^{3}$ a light to be carried in the hand

Note: $* * *, * *$ and $*$ indicate significant at $1 \%, 5 \%$ and $10 \%$ level, respectively. 
Table 8. Change in liability position after ownership of PTOS.

\begin{tabular}{lc|c|c|c|c}
\hline \multicolumn{1}{c}{ Source of credit } & N & $\begin{array}{c}\text { After having } \\
\text { PTOS }\end{array}$ & $\begin{array}{c}\text { Before having } \\
\text { PTOS }\end{array}$ & $\begin{array}{c}\text { Mean } \\
\text { difference }\end{array}$ & $\begin{array}{c}\mathrm{P}(\mathrm{T}<=\mathrm{t}) \\
\text { value }\end{array}$ \\
\hline 1. Commercial bank & 22 & 28,591 & 19,273 & 9,318 & 0.3037 \\
2. Cooperative society & 1 & 5,000 & 0 & 5,000 & - \\
3. Local NGO & 9 & 50,667 & 33,000 & 17,667 & 0.6570 \\
4. Moneylender & 2 & 17,500 & 27,500 & $-10,000$ & 0.7788 \\
5. Relatives & 3 & 8,333 & 1,667 & 6,666 & 0.2522 \\
6. Others & 2 & 20,000 & 5,000 & 15,000 & 0.2048 \\
\multicolumn{1}{c}{ All sources } & & $\mathbf{2 1 , 6 8 2}$ & $\mathbf{1 4 , 4 0 7}$ & $\mathbf{7 , 2 7 5}$ & \\
\hline
\end{tabular}

Impact on food intake: Due to increased income that earned from renting out PTOS service to others, the frequency and quality of food intake were significantly increased in the study areas. One of the highest improvements was reported in the case of weekly intake of milk, egg, and meat. Fish and vegetable intake also increased remarkably (Table 9).

Table 9. Change in food intake pattern after ownership of PTOS.

\begin{tabular}{|c|c|c|c|c|c|}
\hline \multirow[b]{2}{*}{ Food intake pattern } & \multirow[b]{2}{*}{$\mathrm{N}$} & \multicolumn{2}{|c|}{ Frequency of food intake } & \multirow{2}{*}{$\begin{array}{c}\text { Mean } \\
\text { difference }\end{array}$} & \multirow{2}{*}{$\begin{array}{c}\mathrm{P}(\mathrm{T}<=\mathrm{t}) \\
\text { value }\end{array}$} \\
\hline & & $\begin{array}{l}\text { After having } \\
\text { PTOS }\end{array}$ & $\begin{array}{l}\text { Before having } \\
\text { PTOS }\end{array}$ & & \\
\hline 1. Food intake (times/day) & 53 & $3.32(5)$ & 3.15 & $0.17 * *$ & 0.0400 \\
\hline 2. Fish intake (time/week) & 53 & $5.00(25)$ & 3.75 & $1.25 * * *$ & 0.0000 \\
\hline 3. Meat intake (time/month) & 51 & $3.10(30)$ & 2.18 & $0.92 * *$ & 0.0507 \\
\hline 4. Egg intake (time/week) & 52 & $3.10(37)$ & 1.97 & $1.13 * * *$ & 0.0000 \\
\hline 5. Milk intake (time/week) & 53 & $5.79(48)$ & 3.02 & $2.77 * * *$ & 0.0000 \\
\hline 6. Vegetable intake (kg/week) & 53 & $10.94(28)$ & 7.91 & $3.03 * * *$ & 0.0043 \\
\hline
\end{tabular}

Note: $* * *, * *$ and $*$ indicate significant at $1 \%, 5 \%$ and $10 \%$ level, respectively.

Figures within parentheses indicate percent increase over pre-ownership period.

Impact on overall livelihood status: The overall standard of living social status of the service providers of PTOS was improved remarkably. Table 10 showed that irrespective of service providers' category, more than $94 \%$ of respondents used safe drinking water from hand tube-well and use sanitary toilet, and about 50\% extra households get connection of electricity at their residences. Awareness development was another positive impact that was found in the service providers during post-ownership period. It was reported that the awareness of service providers regarding contraceptive use, sending children to school, and consultation with MBBS doctor was increased (6.3-27\%) to some extent. Furthermore, better economic standing enabled them to buy more costly new clothes for several social 
and religious events. It revealed that the members of service providers with local level cooperative society increased by about $74 \%$ in the study areas.

Table 10. Increase in livelihood status before and after ownership of PTOS.

\begin{tabular}{|c|c|c|c|}
\hline \multirow[b]{2}{*}{ Livelihood criteria } & \multicolumn{2}{|c|}{$\%$ responses } & \multirow[b]{2}{*}{$\%$ increased } \\
\hline & $\begin{array}{c}\text { After having } \\
\text { PTOS }\end{array}$ & $\begin{array}{c}\text { Before having } \\
\text { PTOS }\end{array}$ & \\
\hline Sample size $(N)$ & 53 & 53 & 53 \\
\hline 1. Using tube well water & 94.3 & 83.0 & $13.6 *$ \\
\hline 2. Using sanitary toilet & 94.3 & 69.8 & $35.1 * * *$ \\
\hline 3. Using electricity & 56.6 & 37.7 & $50.1 *$ \\
\hline 4. Adopting contraceptive method & 56.6 & 45.3 & $24.9 *$ \\
\hline 5. Sending children to school & 88.7 & 69.8 & $27.1 *$ \\
\hline 6. Consultation with MBBS doctor & 94.3 & 88.7 & 6.3 \\
\hline 7. Buying new cloths in religious festivals & 92.5 & 81.1 & $14.1 *$ \\
\hline 8. Offering gifts in social events & 94.3 & 83.0 & $13.6^{*}$ \\
\hline 9. Membership with cooperative society & 49.1 & 28.3 & $73.5^{* *}$ \\
\hline
\end{tabular}

\subsection{Problems of Service Providers}

About $38 \%$ of total service providers did not face any major problem except few minor things during renting out of PTOS service to the farmers. Among different problems, higher diesel price was ranked first which was mentioned by over $60 \%$ of the service providers. Driving of PTOS by walking sometimes create problem for them. The non-availability and higher price of spare parts and roller jam due to soil store were mentioned by $47.2 \%$ and $28.3 \%$ of the service providers as problems. Some service providers told that trained and efficient driver become scares, especially in the peak season (Rabi season). A few respondents also mentioned that PTOS tilled land with shallow depth (Table 11).

Table 11. Problems encountered by sample service provider of PTOS/HSRT.

\begin{tabular}{l|c|c}
\hline \multirow{2}{*}{\multicolumn{1}{c}{ Type of problem }} & \multicolumn{2}{c}{ Responses $(N=53)$} \\
\cline { 2 - 3 } & Number & $\%$ \\
\hline 1. No problem at all & 20 & 37.7 \\
2. Fuel cost is high & 32 & 60.4 \\
3. Driving by walking & 28 & 52.8 \\
4. Non-availability and higher price of spare parts & 25 & 47.2 \\
5. Soil store in roller/roller jam & 15 & 28.3 \\
6. Scarcity of trained driver & 12 & 22.6 \\
7. Shallow depth in cultivation & 10 & 18.9 \\
8. Others* & 8 & 15.1 \\
\hline
\end{tabular}

* Difficult to drive during rainy season; unable to drive at night; licking fuel from reservoir; problem in radiator and sprocket 


\section{Conclusions and Recommendations}

The study assessed the uses pattern of PTOS operations and its impacts on service providers' livelihood. Custom hiring business through PTOS made a remarkable improvement in the livelihoods of its service providers in the study areas. The average land holding of the service providers was increased to some extent. Significant increase was registered in the value of livestock and poultry resources. The annual household income and number and value of semi-pacca building were also significantly increased by a great extent during postownership period. Both the quantity and value of farm equipment and household assets were significantly increased after having PTOS. The amount of loan received during PTOS ownership period was much higher in the post-ownership period compared to pre-ownership period. The increased income of beneficiaries are mostly spent on farm machinery, nutritious food, cloths, health care, education expenses and making of houses that indicate higher standard of living of service providers. The service providers encountered problems like higher fuel cost, lack of riving facility, non-availability and higher price of spare parts, roller jam, and lack of trained driver.

Due to higher adoption of PTOS, financial support and technical assistance should be made available by the government of Bangladesh for service providers and local manufacturers. Fuel cost may be reduced for small holder farmers. Training on repair and maintenance of PTOS for operators is highly required. Furthermore, research work should be carried out to improve the machine with riding facilities and adding fertilizers application system with existing PTOS that will improve fertilizer uses efficiencies.

Acknowledgement: The financial assistance to carry out the study from Impact Targeting and Assessment Unit of CIMMYT is greatly acknowledged. We also appreciate the help of many others, both individuals and institutions, during conducting this study and regret our inability to acknowledge them all individually.

\section{References}

Barton, D. 2000. Options for farm power use in primary cultivation on small farms: Summary of main findings. J. of Agril. Mach. \& Mech. 4(1): 1-4, 2000.

Grace, P R. 2003. Rice-Wheat System and Climatic Change. Addressing Resource Conservation Issues in Rice-Wheat Systems of South Asia: A Resource Book. RiceWheat Consortium for the Indo-Gangetic Plains - International Maize and Wheat Improvement Center, New Delhi, Pp. 63-67

Haque, M. E., Hossain, M. I., Wohab, M. A., Sayre, K. D., Bell, R.W., Hossain, M. I. and Timsina, J. 2008. Agricultural Mechanization in Bangladesh and Conservation Agriculture: The Opportunities, Priorities, Practices and Possibilities. Forth 
International Conference of Conservation Agriculture. Forthcoming. February 2009, New Delhi, India.

Hossain, M. A. 2014. Agricultural mechanization: The role of BARI. A key-note paper presented in the seminar on 'Farm Mechanization in Bangladesh' organized by the Department of Agricultural and Industrial Engineering, Hajee Mohammad Danesh Science and Technology University, Dinajpur on 31 August 2014.

Islam, M. S. 2000. Socio-economic impacts of power tiller adoption on small farming in Bangladesh. J. of Agril. Mach. \& Mech. 4(1): 77-85.

Quayum, M. A. and A. M. Ali. 2012. Adoption and diffusion of power tillers in Bangladesh. Bangladesh J. Agril. Res. 37(2): 307-325, June 2012.

Miah, M. A. M; Islam, M. S. and Miah, M. T. H. 2002. Socio-economic impacts of farm mechanisation on the livelihoods of rural labourers in Bangladesh. Journal of Farm Economy 12: 147-162.

Miah, M. A. M., Haque, M. E. Baksh, M. E. and Hossain, M. I. 2010. Economic analysis of power tiller operated seeder operations at farm level, Journal of Agricultural Engineering, The Institution of Engineers, Bangladesh, Vol. 38/AE, No. 1, June 2010.

Miah, T. H. 2000. Economic impacts of using power tillers and draught animals for primary cultivation of small farms in Bangladesh. J. of Agril. Mach. \& Mech. 4(1): 69-75.

Sayre, K. D. and Hoobs, P. 2003. Raised Bed System of Cultivation for Irrigated Production Condition. Bed planting course, CIMMYT, Mexico. 